\title{
HOW SELF-CONTROL IMPACT'S ON HAPPINESS AND SATISFACTION WITH LIFE WITH MODERATING ROLE OF LOCUS OF CONTROL
}

\author{
Sajid Hussain \\ Bahauddinzakariya University Multan, Pakistan \\ E-mail: sajid.hussain6441@gmail.com \\ Muhammad Baqir \\ University of Education Lahore, Multan campus, Pakistan \\ E-mail: baqiralisiddique@gmail.com \\ K. M. Anwarul Islam \\ Associate Professor \\ Department of Business Administration \\ The Millennium University, Dhaka, Bangladesh \\ PhD Candidate \\ University of Selangor, Malaysia \\ E-mail: ai419bankingdu@gmail.com \\ Samra Asif \\ Bahauddinzakariya University Multan, Pakistan \\ E-mail: samraahmedtarar@gmail.com
}

\begin{abstract}
Self-control is by all explanations a basic worth affecting how others see us and how we see ourselves. The basic aim of the study is to elaborate the vice versa relationship among the factor to test whether certain psychological variable which increases the satisfaction with life. Component of happiness with the influence of locus of control is correlated with each other which is we find in this research. The participants in the study were 307 students of the different institutes who fill questionnaires through snowball sampling. This had a significant huge relationship with the locus of control. In this study, we use a different technique to find the relationship with data. Firstly we test the reliability of the questionnaire which is used by the different researcher in their research article after this we find the correlation which shows the positive result among the variable. Subsequently, MANOVA and other test were applied in this research to emphasize how self-control plays a major role to enhance the level of happiness which discovered the true meaning of satisfaction. This study recommended that if students and people are good at self-control elements in different situations then they will be happier and satisfied with their life. Moreover, the investigation uncovered that self-control has emphatically corresponded with Happiness, regularity feeling, and satisfaction with life. Research on happiness has caused it conceivable to better comprehend human behaviour in different parts of life.
\end{abstract}

Keywords: Self-Control, Satisfaction with Life, Happiness, Locus of Control. 


\section{INTRODUCTION}

Self-control is one of the most prevalent research topics which entail strong definition confines to permit overview of the consequences. There are some variations between researchers to understand the concept, due to the element that self-control is a complicated phenomenon that comprises many psychological functions and has effective impact on human ordinary performance (Edward Nęcka, 2019)."Self-control is defined "as the ability to modify and control abundantly response tendencies subsequent in the reticence of disagreeable behaviours though stimulating required ones to accomplish the long period objective (De Ridder, 2012).Definitely the most significant challenge in the present life is happiness, which highly effect to determine the genuine significance of life is happiness. Happiness is most substantial factor which reduces the impermanence rate among all human and raise life expectancy between individuals (Beatle et al., 2015). Happiness according to develop model by Seligman (Peterson, 2005), consist of three directions: desire, sense and engagement. Positive reactions inspire to engage in several activities and it's favourable for completion of task at a proficiency level. Consequently, they add to the accomplishment of the success, which provide more positive emotions. A particular wisdom of sense leads to goal achievement. The existence of pleasure (present-oriented) and sense of significance (future-oriented) enhance the contribution of the happiness. Universal life satisfaction, when evaluate on a scale of variety from the assessment of one's life as highly satisfied to very dissatisfying (Diener \& Inglehart, 2013).Happiness is absolutely one of the greatest vision of mankind and every one try is ideal to accomplish it. The ultimate level of happiness arises on individual's valuation of their self and lives. The judgement can be thought such as the assessment prepared concerning fulfilment or they can be expressive which are exposed in reaction to the occasions throughout everyday life (oswald, et, al, \& flower, 2004). Here we characterize happiness as it is regularly characterized in the literature, that is, as far as continuous positive effect, high life fulfilment, and inconsistent negative effect. These three builds are the three essential segments of abstract prosperity, as indicated by (Lyubomksky, 2005).Associate the authenticity of thinking about them as displays of the equivalent hidden develop, we discover that the methods are outstandingly corresponded and normally produce a solitary factor after undesirable influence has remained recoded (Sheldon, 1995). It is critical to note too that we apply a personalized meaning of happiness single that ordinarily depends on individuals' self-reports. We accept this is proper and even vital assumed our opinion that happiness must be characterized from the point of view of the individual. In other words, satisfaction is essentially an abstract singularity for which the last appointed authority must to be "whoever lives inside an individual's skin (Diener E. \&., 1995).Happier people have more postive vision towards life or aparticular events. They have maximum smooth of pleasure towards their family, profession ,education and all the other aspect of whole life (Eysenk, 1996). Rotter (1996)clarifies the the strengthening which are elementary indicators of individual's attitude in long tenure locus of control in his social knowledge Philosophy, as. The idea of locus of control is wide concepts in the perspective to laern difficult things and behaviour's alteration. This thought protect the idea that peoples during their lives, examine the actions as their arrogances or they trust that those suitation result from accidental, luck or external forces (Erdogan, 2003).Characters with inside Loc (locus of control) are vigilant, attentive, leading, faithful on victory, self-assured, and creative. On the further side, the characters with peripheral locus of are least careful, high-flown by the cluster supporters, simply influenced by exterior forces, fewer self-assured and they show unstable presentations (Rotter, 1975).People spread out two mechanism insolences as inner and external by seeing that the supports which they get from 
their earlier capabilities consequence from their specific behaviour or outer forces (Cetin, 2008). In a progression of distributions, we have shown and utilized an instrument for self-detailing life satisfaction as a social marker of how much subjects have figured out how to adapt to various parts of life also, life as an entire. Level of satisfaction with life as an entire can be viewed as synonymous with quality of life. An elective view, in any case, and one to which we buy in, is that to be happy with life as an entire is to be glad Subjects who are at least fulfilled (scale grades 5 and 6) with life as entire we consider to be upbeat Under various conditions it has been demonstrated that undesirable changes in capacity to keep being a functioning member in life lead to a low degree of satisfaction in at least one spaces, and to a low degree of happiness (Braholm et, 1998) .previous many resercher have done work on selfcontrol,happiness, satisfaction with life and locus of control in different realtion but in this reserch my objective is to find out how self-control depend on happiness and satisfaction wit lifewith infulenc e of locus of control. Though self control is most important factor to perform any kind of activity in craving behaviour.To discourse these familiarity gaps, this article examines the observations of self-control affect on happiness, satisfaction with life with the infuence of locus of control. This analysis help to understand the levels of happiness which people are good in self control at different suitation and how they are satisfied with their life by the affecting factor of locus of control.This understanding practical inferences as will be validated later in this article.

\section{Aim of the study}

The "aim of this study" was to identify the association between the self-control with happiness and satisfaction with life for measuring the influence of the Locus of control which is take in this research as moderating variable on the dependent variable which is Happiness, and gratification with life among the students of the different university. We tested that how the self-control is effecting on happiness which makes the positive or the negative in the consequence related to the life or at any stage of life. As responsive study had recommended that there is substantial impact of the self-control on both dependent variables. To test the relationship we develop Hypothesis.

\section{Self-control}

\section{LITERATURE REVIEW}

Self-control has been dissimilar among the most valued assets of human (Hoffman, etal, 2013).Many resercher exploring the clear the concept that self-control as ability or capacity to manage ,control and impressed, desires and have potential to do activities (Hoffman, etal, 2013).Self-control is the skill to control and adapt reponses in order to escape undersirable behaviours, to rise in desirable ones, and reach long-term ambition. Many research has exposed that keeping self-control can be important for health and happiness. People regularly used variation of terms for self-control, inculding determination, grit,self-discipline, willpower, and fortitude. (Moffitt, et, al, \& Arseneault L, 2011).Psychologists basically defines self-control as: The capacity to control practices so as to evade temptations and to accomplish objectives.the ability to delay satisfaction and resist undesirable behaviours or needs. A partial resource that can be down. (Duckworth A, 2013). Researchers have originate that persons who obligate greater self-control are happier and satisfied with their life. .The psychological literature on self-control has demonstrated that people who have strong self-control are generally experienced additional nearness interpersonal relationships (Koval, 2015). However it's possible that persons who have 
extraordinary level of self-control will cooperate with other and they should seldom face the conflicts (Martinsson, 2014).

\section{Happiness}

Happiness can be described as optimistic or negative reactions that concern the optimal level of satisfaction in human life (Diener \& etal, 1995).According to (Jain \& Saeed, 2012)Happiness is results from pleasant feelings of one's emotion in addition to have postive farme of mind towards something. Those people who are happy they offer more help to other's in critical situation and they are creative, highly innovative in doing things, socially active in society, and benevolent mentally and physically. (Diener \& Dean, 2008). An alternative forecast is that feeling of happiness is relate on different type of culture. For instance, fair of warmth is greater in wealthier countries as compare to poorer countries, where might be happiness depend more fulfillment of basic needs. (Diener \& Tay, 2011). There was a major improvement in our skill to evaluate happiness and our self-assurance in the capacity of happiness (Biswas-Diener, 2008). This point is so significant that is deserves more consideration. It is hard to elaborate the scientific study of happiness without considering confidence to measure happiness. Happiness can remain simply understood by way of a replacement of satisfaction with one's life, in the alliance of wellbeing as advised by (Diener). Nevertheless, the author never actually saw satisfaction of life in term of assessment. The meaning of happiness is that a person is glad or satisfied with their life, without wondering about the presence and absence of particular feelings, but sometime positive results of one's estimate at certain values (Shin \& Irvine, 2015). Happiness can be characterized as how many individuals absolutely evaluate their life circumstance. (Veenhoven, 1996) What's more, relies upon an assortment of individual and social qualities. These qualities vary in the fact that they are so critical to every person and are estimated by ordinal positioning. Happiness is regularly characterized as far as carrying on with a decent life, in preference to humble emotion.

\section{Locus of control}

The idea of LoC ("locus of control"), which started in the social learning concept of American clinician Rotter (1966), manages how much individuals have learnt to see their lives' incidents as either heavily influenced by their own inner attitudes, attributes, or under outside control (Reich, 2017).The locus of control indicates to a person's observation where he recognizes the results of events throughout his life as capacity of his behaviour or qualities. In this manner, the locus of control has a resilient relationship with a person's behaviour. Locus of control, as directed by (Rotter J. , 1966) indicates to one's faith in their capacities to control life events. A somebody with an inside LoC ("locus of control") accepts that consequences are identified with their behaviour or individual security while a specific with an outer Loc(locus of control) accepts that results are not identified with their conduct however to outside powers past their control. According to (Marks, 1998) People with an exterior LoC ("locus of control") may distinguish existence happenings to be regulator by accidental, or luck. Although the people who have inner locus of control are further probable to transform their behaviour subsequent as compare to external LoC("locus of control"). Many researchers recommended that motivation is related to the locus of control when peoples and mostly students given control over instruction. (Keller et al, 1983) Stated that locus of control has been extremely linked with the approaches and then study behaviours of dissimilar subjects who remained actually permitted to resistor teaching. Because of its significance, locus of control turned into a critical variable in different research 
fields. Where the importance of the develop of apparent control by inner or outer elements has been presented As indicated by the definition of Locus of Control is an idea as to whether the life of an individual is constrained by himself or herself or by some outside forces. An individual's comprehensive opinion about inner (self) versus outside (situation or others) control is called locus of control approving to (Nelson, 1997). Locus of Control is view of who controls results and it has been perceived that this observation is significant in shaping behaviour (Harris, 2006).

\section{Satisfaction with life}

"Satisfaction with life" is a person's intellectual appraisals of complete value of the life or perspectives toward exact aspect such as intimate, colleagues, groups and the society (Suldo, al S.M., \& al K.N Riley, 2006). Life-satisfaction, its antecedents and outcomes have been read experimentally for different purposes. Life satisfaction is characterized as people's emotional valuations of the nature for their survives (Diener \& al E., 2013). Life satisfactions characterized as people's intellectual appraisals of the nature of their lives. Many researchers have originate that satisfaction with life relates to various positive consequences including subjective wellbeing (Gilman, al R, \& S, 1997), completing connection with others, optimum physical effective(Lewis, 2010), family relationship worth (Dew, 1994) important of self -esteem (Zhang, al L., \& J., 2002), positive association with in classroom with others, self confidence in class school commitment (Doğan, U., \& Çelik, E., 2014) personal pleasure forgiveness (Eldeleklioğlu, J., 2015), and benevolent attachment (Bendayan, 2013). Satisfaction with life mentions to a reasoning judgmental method said by (Shin, D. C., \& Johnson, D. M., 1978) define satisfaction with life as a worldwide appraisal of an individual's person satisfaction as indicated by his select criteria. One of the most ensconces pointers of wellbeing and positive working among new people (S., 2006) .Satisfaction with Life suggests to a judgmental and intellectual procedure (Diener \& E. R., 1985) in which persons estimate the worth of their life created on a number of criteria. "Satisfaction with life" is an individual opinion broad-spectrum to evaluate the entirely of one's life or other some characteristic of life likewise life with family and academic experience; conclusively satisfaction with life is the balance consideration of among individual aim and currently state of the particular person. In other way the superior gap amongst the level of singular desires and the current state of the person is ultimately effect the satisfaction of the life negatively (pavot, 1993).

\section{HYPOTHESIS}

This study is determined the connection between self-control, happiness satisfaction with life accenting on mediating consequence of locus of control.

$\mathrm{H}_{1}$ : self-control is positively related to happiness.

$\mathrm{H}_{2}$ : people who have strong locus of control have significant impact on satisfaction with life.

$\mathrm{H}_{3}$ : Locus of control moderator has significant relationship with happiness.

$\mathrm{H}_{4}$ : Locus of control moderator has significant relationship with satisfaction with life. 


\section{THEORETICAL FRAMEWORK AND RESEARCH MODEL}

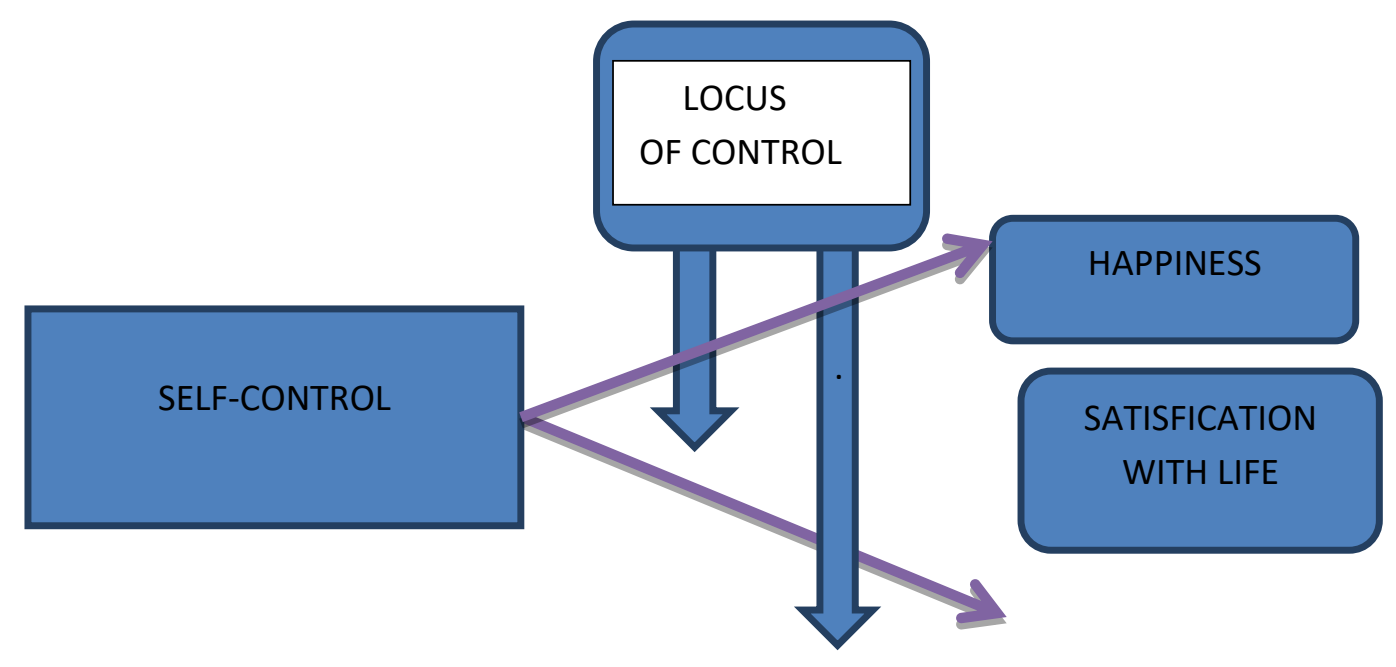

Figure 1. Conceptual Framework

\section{Research model}

A review survey was utilized to accumulate the essential data. The questionnaire is composed of four scales, namely self-control, locus of control, happiness and "satisfaction with life". This study is designed to analyse the relationship of "self-control" with happiness and satisfaction of life with the moderating variable locus of control is significantly interrelated to each other. The theoretical frame work depicting this relationship presumed that is positive. It is context the base study considers in the series of qualitative studies. Its consist basic primary approached (questionnaire). The questionnaire is composed of two different type of scales included nominal, (yes, No) likert scale which is start from (strongly agree, to strongly disagree)

\section{Data collection Tools}

\section{METHODOLOGY}

In this study we are used questionnaire method. For observing the result which consist only 67 questions to get the primary data.

\section{Procedure}

Respondents were invited to participate in study on volunteer basis. The questionnaire were deliver to the participant were in two ways. One is hard copy distributed among students and second one is online administrative (Google form). The whole process of answering took about 50 minutes for completing one questionnaire.

\section{Data Analysis}

The data analysis included calculation of descriptive statistics for the variables via the questionnaire for overall the measure. The reliability of data consistency is calculated through different testing tools. Included Mean, Median Mode, Correlation, Regression or cronbach's Alpha were utilized in order to influence the capacity and direction of correspondence among the variable. 


\section{Measure}

The participants filled the finalized questionnaires. Further they were requested to provide basic demographic information, which is categorized on gender, phase, and conjugal status. We second-hand the subsequent methods. The self-control scale by (Tangney et al, 2004)was used to amount constitution self-control. Basically it's consist of 13 statements in the adopted questionnaire (e.g., "I have a hard time breaking bad habits") regarded on a 5 option. Here we test the reliability of the scale through SPSS software in which we find Cronbach's $\alpha$ which .495 is. The total number of statement which is estimated here is 12 and 1 is excluded here to balance the reliability of the scale due to increase the reliability. Below the table show the reliability scale of self-control.

"Self-control"

"Reliability Statistics"

\begin{tabular}{|l|ll|}
\hline $\begin{array}{l}\text { "Cronbach's } \\
\text { Alpha" }\end{array}$ & $\begin{array}{l}\text { "N } \\
\text { Items" }\end{array}$ \\
\hline .495 & 12 \\
\hline
\end{tabular}

The Oxford Happiness Questionnaire was created by psychologists (Hills, 2002) was utilized to quantify the degree to which individuals measured their happiness. It contains 29 items regarded on a 6-point scale. An instance item is: "I don't feel particularly pleased with way I am'" the value of Cronbach's $\alpha$ was .773 which is acceptable for the reliability. Below the table show the value of reliability scale of happiness.

\section{"Happiness"}

"Reliability Statistics"

\begin{tabular}{|l|ll|}
\hline $\begin{array}{l}\text { "Cronbach's } \\
\text { Alpha" }\end{array}$ & $\begin{array}{l}\text { "N } \\
\text { Items" }\end{array}$ \\
\hline .773 & 29 \\
\hline
\end{tabular}

The Satisfaction with Life Scale ( (Diener, 1985)Comprising of five statements anticipated to instrument worldwide intellectual decisions of "satisfaction with life"(e.g., "so far I have gotten the important things I want in life"') the following are based on five statements scale. Utilizing the $1-7$ points' .The reliability of the scale (Cronbach's $\alpha$ ) was .665 which is questionable and below the table shows the value of the satisfaction with life.

\section{"Satisfaction with Life"}

"Reliability Statistics

\begin{tabular}{|l|l|}
\hline $\begin{array}{l}\text { "Cronbach's } \\
\text { Alpha" }\end{array}$ & $\begin{array}{l}\text { "N } \\
\text { Items" of }\end{array}$ \\
\hline .655 & 5 \\
\hline
\end{tabular}

The "locus of control" scale developed by (Bernardi, 1997) this scale is used to measure the effect of the locus of control on the self-control, happiness, and satisfaction with life. In this examination the locus of control is use as the moderating which show the influence. LOC consist on the 20 statement. (e.g. "I don't really believe in luck or chance') The result scored by giving option which is (Yes-or -No). The reliability of the scale check through the software 
SPSS. Total number of the statement is 20 but to increase the reliability of the scale we exclude the 2 statement which effect the reliability of the scale after this the chronbach's alpha value of the 18 items is "(Cronbach's $\alpha)$ " is .464. It's approximately near to the 5 which is place on questionable in chronbach's alpha. The below table show the reliability statistics of the variable.

\section{"Locus of Control"}

"Reliability Statistics"

\begin{tabular}{|l|ll|}
\hline $\begin{array}{l}\text { "Cronbach's } \\
\text { Alpha" }\end{array}$ & $\begin{array}{l}\text { "N } \\
\text { Items" of }\end{array}$ \\
\hline .464 & 18 \\
\hline
\end{tabular}

\section{RESULTS AND DISCUSSION}

This section reports on and deliberates the consequences of the survey. As we can see in the Tables 1 to 6 . In this we make questionnaire on the Google from for collecting response and we get 307 responses as the sample of the study. Correlations between the self-control, happiness and satisfaction with life which shown in table no 1 reveals that self-control positively associated with the happiness and satisfaction with life. Along these lines, presently you comprehend what the positive or negative sign methods on a connection coefficient. It discloses to you whether the two factors move a similar way or inverse bearings. It likewise discloses to you the general course of the line you would see on as scatter plot indicating the entirety of the individuals used to calculate the correlation. At whatever Point we graph two variables that move in similar way, the mark we draw will for the most part go from the base left to the upper right of the diagram. We call this a positive relationship. A positive connection implies that the two factors move a similar way - as one goes up, the different goes up, or the other way around. We call this a positive relationship since when we do the condition to think of our connection coefficient, the outcome will be a positive number. It tends to be somewhere in the range of +0.01 as far as possible up to +1.00 . In this we see there is a positive correlation between the dependent or independent variable with the effect of "locus of control" and the value of the all variable is significant which is shown in table below.

Table 1. Correlations

\begin{tabular}{|c|c|c|c|c|c|}
\hline & & $\begin{array}{l}\text { "Self- } \\
\text { Control" }\end{array}$ & "Happiness" & $\begin{array}{l}\text { "Satisfaction } \\
\text { with Life"" }\end{array}$ & $\begin{array}{ll}\text { "Locus } & \text { of } \\
\text { Control" } & \end{array}$ \\
\hline \multirow[t]{3}{*}{$\begin{array}{l}\text { "Self- } \\
\text { Control" }\end{array}$} & $\begin{array}{l}\text { "Pearson } \\
\text { Correlation" }\end{array}$ & 1 & -.028 & -.088 & $-.270^{* * *}$ \\
\hline & "Sig. (2-tailed)" & & .620 & .123 & .000 \\
\hline & "N" & “307” & “307” & 307 & 307 \\
\hline \multirow[t]{3}{*}{ "Happiness" } & $\begin{array}{l}\text { "Pearson } \\
\text { Correlation" }\end{array}$ & -.028 & 1 & $.479^{* * *}$ & $.377^{* *}$ \\
\hline & "Sig. (2-tailed)" & .620 & & .000 & .000 \\
\hline & "N" & “307” & “307” & 307 & 307 \\
\hline $\begin{array}{l}\text { "Satisfaction } \\
\text { with Life" }\end{array}$ & $\begin{array}{l}\text { "Pearson } \\
\text { Correlation" }\end{array}$ & -.088 & $.479^{* *}$ & 1 & $.293^{* *}$ \\
\hline
\end{tabular}




\begin{tabular}{|l|l|l|l|l|l|}
\hline & & & & & \\
\cline { 2 - 6 } & "Sig. (2-tailed)" & .123 & .000 & & .000 \\
\cline { 2 - 6 } & "N" & "'307" & 307 & 307 & 307 \\
\hline \multirow{3}{*}{$\begin{array}{l}\text { Control" } \\
\end{array}$} & $\begin{array}{l}\text { "Pearson } \\
\text { Correlation" }\end{array}$ & -.270 "** & $.377^{* *}$ & $.293^{* * *}$ & 1 \\
\cline { 2 - 6 } & "Sig. (2-tailed)" & .000 & .000 & .000 & \\
\cline { 2 - 6 } & "N" & 307 & 307 & 307 & 307 \\
\hline
\end{tabular}

The descriptive statistics for the variable of self-control Happiness, satisfaction with and locus of control are presented in Table 2. This is categorizing by minimum, maximum, mean and most important standard deviation. As, can be perceived, women filled the high number of response which demonstrated that over all the self-control have optimistic influence on their life in different aspect. While in the descriptive statistics for all variables the lowest scores are beyond the objective the maximum 1 is place on the 3 rd value which is the dependent variable satisfaction with life and here all the means are exceeding the average. Previously we test the reliability of the each scale which is approximately is acceptable. The values of means in the table indicate that satisfaction with life have higher value when you have significantly command our the self-control then there is positive impact on the satisfaction with life as the mean value proportionally shown in the table the value of means is $(\mathrm{p}<3.65472)$. In summary, for this illustration respondents give their positive emotion regarding their happiness, and satisfaction with life and flourishing the measure of the experienced about the self-control. People who have strongly balance their self-control are efficiently happier and associated satisfied with their life in the perspective of the utilizing the locus of control. The whole variance between the all dependent and independent variable is get more positively effect is satisfaction with life (mean difference ' $p<3.65472$ ', significantly relate with the std.deviation ' $p<1.055643$ '). In this happiness added " $=.533898$ ' to explained the influence of self-control. We were likewise keen on researching how much satisfaction with life variance was represented by happiness. (Variance $=0.899472$ ). In this descriptive statistics the hypothesis $\mathrm{H} 1$ is prove that self-control is definitely related to happiness.

Table 2. Descriptive Statistics

\begin{tabular}{|l|l|l|l|l|l|}
\hline & "N" & "Minimum" & "Maximum" & "Mean" & $\begin{array}{l}\text { "Std. } \\
\text { Deviation" }\end{array}$ \\
\hline Self-Control & 307 & 1.417 & 4.167 & 2.77389 & .478922 \\
\hline Happiness & 307 & 1.621 & 5.276 & 3.37066 & .533898 \\
\hline $\begin{array}{l}\text { "Satisfactionwith } \\
\text { Life" }\end{array}$ & 307 & 1.000 & 6.600 & 3.65472 & 1.055643 \\
\hline $\begin{array}{l}\text { "Locusof } \\
\text { Control" }\end{array}$ & 307 & 1.167 & 2.000 & 1.55248 & .156171 \\
\hline $\begin{array}{l}\text { Valid } \\
\text { (listwise) }\end{array}$ & 307 & & & & \\
\hline
\end{tabular}

\section{Manova Test Results}

Following test results are statistically insignificant which is desired one because here we are in the favour that Null Hypothesis should not be rejected. H0 the watched covariance frameworks 
of the reliant factors are equivalent across groups. Here $\mathrm{P}$ value is .308 that is greater than the 0.05 in the light of above result we fail to reject the Null Hypothesis that is desirable. If the BOX'S m test results are significant and the Null hypothesis has been rejected than further in multivariate analysis table, we will analyse the results of Pillai's Trace test. On the other hand, if results are insignificant what's more, neglect to dismiss the Null theory than researcher is advised to analyse the Wilks' Lamba results is in the case here.

Table 3. Box's Test of Equality of Covariance Matrices

\begin{tabular}{|l|l|}
\hline "Box's M" & "71".930 \\
\hline "F" & "1".083 \\
\hline “df1" & 60 \\
\hline “df2" & 11817.003 \\
\hline Sig. & .308 \\
\hline
\end{tabular}

Multivariate tests summarize results of Wilks' Lambda which is a proportion of the present of change in the dependent factors that is *not explained* by contrasts in the degree of the independent variable. Wilks' Lambda differs somewhere in the range of 1 and zero(i.e., no variance that isn't clarified by the independent variable). Here independent variable is selfcontrol (SC) while the mediating variable is Locus of Control (LC) here the value of Wilks' Lambda is 0.991 which is much higher and close to 1 , associated F is 1.312 , sig value is 0.271 which is greater than the 0.05 It means an insignificant multivariate main effect for Self-control SC, Wilks' $\lambda=.991, \mathrm{~F}(2,276)=1.312$, Sig $>0.05$, fractional eta squared (related with the fundamental impact ofself-control) $=0.009$ and observed power (the power to detect the main effect $)=0.283$. These are very poor of self-control on dependent variables while LC was used as a mediating variable. while the mediating variable is Locus of Control (LC) here the value of Wilks' Lambda is 0.711 which is better result as compare to independent variables, associated F is 3.414, sig value is 0.00 which is $<0.05$ It means a significant multivariate main effect for Locus of control LC, Wilks' $\lambda=.711, \mathrm{~F}(30,552)=3.414$, Sig $<0.05$, partial eta squared (associated with the main effect of self-control) $=0.156$ and observed power (the power to detect the main effect $)=1.0$. These are better results as compare to the self-control effect.

Table 4. Multivariate Tests

\begin{tabular}{|c|c|c|c|c|c|c|c|c|c|}
\hline \multicolumn{2}{|l|}{$\begin{array}{l}\text { "Effect } \\
\text { Value" }\end{array}$} & $\begin{array}{l}\text { "Va } \\
\text { lue" }\end{array}$ & "F" & $\begin{array}{l}\text { "Hypoth } \\
\text { esis df" }\end{array}$ & $\begin{array}{l}\text { "Error } \\
\mathrm{df} "\end{array}$ & $\begin{array}{l}\text { "Si } \\
\text { g". }\end{array}$ & $\begin{array}{l}\text { "Parti } \\
\text { al Eta } \\
\text { Squar } \\
\text { ed" }\end{array}$ & $\begin{array}{l}\text { "Nonce } \\
\text { nt. } \\
\text { Parame } \\
\text { ter" }\end{array}$ & $\begin{array}{l}\text { "Obser } \\
\text { ved } \\
\text { Power" } \\
\text { d }\end{array}$ \\
\hline \multirow[t]{4}{*}{ "Intercept" } & $\begin{array}{l}\text { "Pillai's"“"Trac } \\
\text { e" }\end{array}$ & .571 & $\begin{array}{l}183.8 \\
39^{\mathrm{b}}\end{array}$ & 2.000 & $\begin{array}{l}276.00 \\
0\end{array}$ & .000 & .571 & $\begin{array}{l}367.67 \\
7\end{array}$ & 1.000 \\
\hline & $\begin{array}{l}\text { "Wilks' } \\
\text { "Lambda" }\end{array}$ & .429 & $\begin{array}{l}183.8 \\
39^{\mathrm{b}}\end{array}$ & 2.000 & $\begin{array}{l}276.00 \\
0\end{array}$ & .000 & .571 & $\begin{array}{l}367.67 \\
7\end{array}$ & 1.000 \\
\hline & $\begin{array}{l}\text { "Hotelling's"، } \\
\text { Trace" }\end{array}$ & $\begin{array}{l}1.33 \\
2\end{array}$ & $\begin{array}{l}183.8 \\
39^{\mathrm{b}}\end{array}$ & 2.000 & $\begin{array}{l}276.00 \\
0\end{array}$ & .000 & .571 & $\begin{array}{l}367.67 \\
7\end{array}$ & 1.000 \\
\hline & "Roy's"'Larg & 1.33 & 183.8 & 2.000 & 276.00 & .000 & .571 & 367.67 & 1.000 \\
\hline
\end{tabular}




\begin{tabular}{|c|c|c|c|c|c|c|c|c|c|}
\hline & est"“"Root" & 2 & $39^{b}$ & & 0 & & & 7 & \\
\hline \multirow[t]{4}{*}{$\mathrm{SC}$} & $\begin{array}{l}\text { "Pillai's" } \\
\text { "Trace" }\end{array}$ & $\begin{array}{l}\text { ".00 } \\
9 "\end{array}$ & $\begin{array}{l}\text { "1.31 } \\
2, \mathrm{~b}\end{array}$ & $" 2.000 "$ & $\begin{array}{l}\text { "276.0 } \\
00 "\end{array}$ & .271 & .009 & 2.625 & .283 \\
\hline & $\begin{array}{l}\text { "Wilks" } \\
\text { "Lambda" }\end{array}$ & $\begin{array}{l}\text { ".99 } \\
1 "\end{array}$ & $\begin{array}{l}\text { "1.31 } \\
2 " \mathrm{~b}\end{array}$ & $" 2.000 "$ & $\begin{array}{l}\text { "276.0 } \\
00 "\end{array}$ & .271 & .009 & 2.625 & .283 \\
\hline & $\begin{array}{l}\text { "Hotelling's"، } \\
\text { Trace" }\end{array}$ & .010 & $\begin{array}{l}\text { "1.31 } \\
2, \mathrm{~b}\end{array}$ & "2.000" & $\begin{array}{l}\text { "276.0 } \\
00 "\end{array}$ & .271 & .009 & 2.625 & .283 \\
\hline & $\begin{array}{l}\text { "Roy's""“Larg } \\
\text { est""Root" }\end{array}$ & .010 & $\begin{array}{l}\text { "1.31 } \\
2, \mathrm{~b}\end{array}$ & $" 2.000 "$ & $\begin{array}{l}\text { "276.0 } \\
00 "\end{array}$ & .271 & .009 & 2.625 & .283 \\
\hline \multirow[t]{5}{*}{$\mathrm{LC}$} & $\begin{array}{l}\text { "Pillai's"'Trac } \\
\text { e" }\end{array}$ & .296 & 3.202 & 30.000 & $\begin{array}{l}554.00 \\
0\end{array}$ & .000 & .148 & 96.071 & 1.000 \\
\hline & $\begin{array}{l}\text { "Wilks"“'Lam } \\
\text { bda" }\end{array}$ & .711 & $\begin{array}{l}3.414 \\
\mathrm{~b}\end{array}$ & 30.000 & $\begin{array}{l}552.00 \\
0 \\
\end{array}$ & .000 & .156 & $\begin{array}{l}102.41 \\
5\end{array}$ & 1.000 \\
\hline & $\begin{array}{l}\text { "Hotelling's"، } \\
\text { Trace" }\end{array}$ & .396 & 3.626 & 30.000 & $\begin{array}{l}550.00 \\
0\end{array}$ & .000 & .165 & $\begin{array}{l}108.77 \\
9\end{array}$ & 1.000 \\
\hline & $\begin{array}{l}\text { "Roy's"“"Larg } \\
\text { est"“"Root" }\end{array}$ & .369 & $\begin{array}{l}6.807 \\
c\end{array}$ & 15.000 & $\begin{array}{l}277.00 \\
0 \\
\end{array}$ & .000 & .269 & $\begin{array}{l}102.10 \\
7\end{array}$ & 1.000 \\
\hline & & & & & & & & & .330 \\
\hline \multirow[t]{4}{*}{ "Gender" } & $\begin{array}{l}\text { "Pillai's"'Trac } \\
\text { e" }\end{array}$ & .011 & 1.559 & 2.000 & $\begin{array}{l}276.00 \\
0\end{array}$ & .212 & .011 & 3.118 & \\
\hline & $\begin{array}{l}\text { "Wilks"“Lam } \\
\text { bda" }\end{array}$ & .989 & ${ }_{b} 1.559$ & 2.000 & $\begin{array}{l}276.00 \\
0 \\
\end{array}$ & .212 & .011 & 3.118 & .330 \\
\hline & $\begin{array}{l}\text { "Hotelling's"، } \\
\text { Trace" }\end{array}$ & .011 & $\begin{array}{l}1.559 \\
\mathrm{~b}\end{array}$ & 2.000 & $\begin{array}{l}276.00 \\
0 \\
\end{array}$ & .212 & .011 & 3.118 & .330 \\
\hline & $\begin{array}{l}\text { "Roy's""'Larg } \\
\text { est""Root" }\end{array}$ & .011 & $\begin{array}{l}1.559 \\
\text { b }\end{array}$ & 2.000 & $\begin{array}{l}276.00 \\
0\end{array}$ & .212 & .011 & 3.118 & .330 \\
\hline \multirow[t]{4}{*}{$\begin{array}{l}\text { LC } \\
\text { "Gender" }\end{array}$} & $\begin{array}{l}\text { "Pillai's"'Trac } \\
\text { e" }\end{array}$ & .105 & 1.285 & 24.000 & $\begin{array}{l}554.00 \\
0 \\
\end{array}$ & .165 & .053 & 30.851 & .924 \\
\hline & $\begin{array}{l}\text { "Wilks" } \\
\text { "Lambda" }\end{array}$ & .897 & ${ }_{\mathrm{b}}^{1.284}$ & 24.000 & $\begin{array}{l}552.00 \\
0 \\
\end{array}$ & .166 & .053 & 30.827 & .923 \\
\hline & $\begin{array}{l}\text { "Hotelling's"، } \\
\text { Trace" }\end{array}$ & .112 & 1.283 & 24.000 & $\begin{array}{l}550.00 \\
0 \\
\end{array}$ & .167 & .053 & 30.803 & .923 \\
\hline & $\begin{array}{l}\text { "Roy's""Larg } \\
\text { est'"Root" }\end{array}$ & .074 & 1.716 & 12.000 & $\begin{array}{l}277.00 \\
0 \\
\end{array}$ & .063 & .069 & 20.586 & .862 \\
\hline
\end{tabular}

Levene's trial of equity of error variances null hypothesis is H0: The error difference of the dependent variables is equivalent across groups. It is desirable that null hypothesis should not be rejected. Levene's test of equally of error variances F-test results are 1.001 and 1.355 for Happiness and fulfilment with life separately suggest we fail to reject null hypothesis and their corresponding Sig. values are 0.469 , and 0.114 which all are greater than $5 \%$ confirm that there is equal variance (Homosksedastic) across dependent variables (Happiness with satisfaction with life and satisfaction with existence with happiness) it is desirable. 
Table 5. Levene's Test of Equality of Error Variances

\begin{tabular}{|l|l|l|l|l|}
\hline & "F" & "df1" & "df2" & "Sig" \\
\hline Happiness & "1.001" & "28" & "278" & .469 \\
\hline $\begin{array}{l}\text { Satisfaction with } \\
\text { Life }\end{array}$ & 1.355 & 28 & 278 & .114 \\
\hline
\end{tabular}

"Tests the null hypothesis that the error variance of the dependent variable is equal across groups"

Tests of among-Subjects Effects table summarize the results of individual variables and show its significance. F stats values of independent variable self-control on each dependent variable Happiness and Satisfaction with life are 2.6 and 0.1491 respectively and their corresponding sig values are greater than $5 \%$ for Happiness and Satisfaction with life it means self-control has no impact on Happiness and Satisfaction with life. Partial eta squared for Happiness and Satisfaction with life are 0.009 and 0.001 respectively indicate strength of impact is week. Finally observed power for Happiness and Satisfaction with life is 0.358 and 0.06 respectively indicated self-control has low power to detect Happiness and Satisfaction with life. For both insignificant variables, results are very week. Locus of control shown significant impact on both dependent variables $F$ static is 6.264 and 3.109 respectively for both dependent variables. Sig value is lesser than 0.05 has significant impact on happiness and satisfaction with life. Partial eta squared is .253 and .144 respectively indicate strength of impact is good.

Finally, the observed power for Happiness and Satisfaction with life is 1.000 and .998 respectively has power to detect happiness and satisfaction with life for significant results are good.

Table 6. Tests of Between-Subjects Effects

\begin{tabular}{|c|c|c|c|c|c|c|c|c|c|}
\hline $\begin{array}{l}\text { "Sour } \\
\text { ce" }\end{array}$ & $\begin{array}{l}\text { "Depe } \\
\text { ndent } \\
\text { variabl } \\
\text { e" }\end{array}$ & $\begin{array}{l}\text { "Typ } \\
\text { e III } \\
\text { Sum } \\
\text { of } \\
\text { Squa } \\
\text { res" }\end{array}$ & "df & $\begin{array}{l}\text { "Mean""، } \\
\text { Square" }\end{array}$ & "F" & $\begin{array}{l}\text { "Si } \\
\text { g". }\end{array}$ & $\begin{array}{l}\text { "Partial""Eta" } \\
\text { "Squared" }\end{array}$ & $\begin{array}{l}\text { "Noncent""P } \\
\text { arameter" }\end{array}$ & $\begin{array}{l}\text { "Obse } \\
\text { rved } \\
\text { Power } \\
\text {,c }\end{array}$ \\
\hline $\begin{array}{l}\text { Corre } \\
\text { cted } \\
\text { Mode } \\
1\end{array}$ & $\begin{array}{l}\text { Happin } \\
\text { ess } \\
\text { Satisfa } \\
\text { ction } \\
\text { with } \\
\text { Life }\end{array}$ & $\begin{array}{l}24.88 \\
7^{\mathrm{a}} \\
57.50 \\
1^{\mathrm{b}}\end{array}$ & $\begin{array}{l}29 \\
29\end{array}$ & $\begin{array}{l}.858 \\
1.983\end{array}$ & $\begin{array}{l}3.81 \\
3 \\
1.93 \\
7\end{array}$ & $\begin{array}{l}.00 \\
0 \\
.00 \\
4\end{array}$ & $\begin{array}{l}.285 \\
.169\end{array}$ & $\begin{array}{l}110.590 \\
56.183\end{array}$ & $\begin{array}{l}1.000 \\
.997\end{array}$ \\
\hline $\begin{array}{l}\text { Interc } \\
\text { ept }\end{array}$ & $\begin{array}{l}\text { Happin } \\
\text { ess } \\
\text { Satisfa } \\
\text { ction } \\
\text { with }\end{array}$ & $\begin{array}{l}80.64 \\
1 \\
110.7 \\
06\end{array}$ & $\begin{array}{l}1 \\
1\end{array}$ & $\begin{array}{l}80.641 \\
110.706\end{array}$ & $\begin{array}{l}358 . \\
337 \\
108 . \\
168\end{array}$ & $\begin{array}{l}.00 \\
0 \\
.00 \\
0\end{array}$ & $\begin{array}{l}.564 \\
.281\end{array}$ & $\begin{array}{l}358.337 \\
108.168\end{array}$ & $\begin{array}{l}1.000 \\
1.000\end{array}$ \\
\hline
\end{tabular}




\begin{tabular}{|c|c|c|c|c|c|c|c|c|c|}
\hline & Life & & & & & & & & \\
\hline SC & $\begin{array}{l}\text { Happin } \\
\text { ess } \\
\text { Satisfa } \\
\text { ction } \\
\text { with } \\
\text { Life }\end{array}$ & $\begin{array}{l}.578 \\
.153\end{array}$ & $\begin{array}{l}1 \\
1\end{array}$ & $\begin{array}{l}.578 \\
1 \\
.153\end{array}$ & $\begin{array}{l}2.56 \\
7 \\
.149\end{array}$ & $\begin{array}{l}.11 \\
0 \\
.69 \\
9\end{array}$ & $\begin{array}{l}.009 \\
.001\end{array}$ & $\begin{array}{l}2.567 \\
.149\end{array}$ & $\begin{array}{l}.358 \\
.067\end{array}$ \\
\hline LC & $\begin{array}{l}\text { Happin } \\
\text { ess } \\
\text { Satisfa } \\
\text { ction } \\
\text { with } \\
\text { Life }\end{array}$ & $\begin{array}{l}21.14 \\
6 \\
47.73 \\
5\end{array}$ & $\begin{array}{l}15 \\
15\end{array}$ & $\begin{array}{l}1.410 \\
3.182\end{array}$ & $\begin{array}{l}6.26 \\
4 \\
3.10 \\
9\end{array}$ & $\begin{array}{l}.00 \\
0 \\
.00 \\
0\end{array}$ & $\begin{array}{l}.253 \\
.144\end{array}$ & $\begin{array}{l}93.965 \\
46.640\end{array}$ & $\begin{array}{l}1.000 \\
.998\end{array}$ \\
\hline $\begin{array}{l}\text { Gend } \\
\text { er }\end{array}$ & $\begin{array}{l}\text { Happin } \\
\text { ess } \\
\text { Satisfa } \\
\text { ction } \\
\text { with } \\
\text { Life }\end{array}$ & $\begin{array}{l}.435 \\
2.461\end{array}$ & $\begin{array}{l}1 \\
1\end{array}$ & $\begin{array}{l}.435 \\
2.461\end{array}$ & $\begin{array}{l}1.93 \\
1 \\
2.40 \\
5\end{array}$ & $\begin{array}{l}.16 \\
6 \\
.12 \\
2\end{array}$ & $\begin{array}{l}.007 \\
.009\end{array}$ & $\begin{array}{l}1.931 \\
2.405\end{array}$ & $\begin{array}{l}.283 \\
.339\end{array}$ \\
\hline $\begin{array}{l}\text { LC * } \\
\text { Gend } \\
\text { er }\end{array}$ & $\begin{array}{l}\text { Happin } \\
\text { ess } \\
\text { Satisfa } \\
\text { ction } \\
\text { with } \\
\text { Life }\end{array}$ & $\begin{array}{l}4.630 \\
12.52 \\
2\end{array}$ & $\begin{array}{l}12 \\
12\end{array}$ & $\begin{array}{l}.386 \\
1.043\end{array}$ & $\begin{array}{l}1.71 \\
5 \\
1.02 \\
0\end{array}$ & & $\begin{array}{l}.069 \\
.042\end{array}$ & $\begin{array}{l}20.576 \\
12.235\end{array}$ & $\begin{array}{l}.862 \\
.591\end{array}$ \\
\hline Error & $\begin{array}{l}\text { Happin } \\
\text { ess } \\
\text { Satisfa } \\
\text { ction } \\
\text { with } \\
\text { Life }\end{array}$ & $\begin{array}{l}62.33 \\
7 \\
283.4 \\
99\end{array}$ & $\begin{array}{l}27 \\
7 \\
27 \\
7 \\
.22 \\
5 \\
1.0 \\
23\end{array}$ & & & & & & \\
\hline Total & $\begin{array}{l}\text { Happin } \\
\text { ess } \\
\text { Satisfa } \\
\text { ction } \\
\text { with } \\
\text { Life }\end{array}$ & $\begin{array}{l}3575 . \\
162 \\
4441 . \\
600\end{array}$ & $\begin{array}{l}30 \\
7 \\
30 \\
7\end{array}$ & & & & & & \\
\hline $\begin{array}{l}\text { Corre } \\
\text { cted } \\
\text { Total }\end{array}$ & $\begin{array}{l}\text { Happin } \\
\text { ess } \\
\text { Satisfa } \\
\text { ction } \\
\text { with } \\
\text { Life } \\
\end{array}$ & $\begin{array}{l}87.22 \\
4 \\
341.0 \\
01\end{array}$ & $\begin{array}{l}30 \\
6 \\
30 \\
6\end{array}$ & & & & & & \\
\hline
\end{tabular}


\begin{tabular}{|l|l|l|l|l|l|l|l|l|}
\hline & & & & & & & & \\
\hline
\end{tabular}

a. "R Squared" = 285 ("Adjusted R Squared" $=.211$ )

b. "R Squared" = .169 ("Adjusted R Squared" =.082)

c. "Computed using alpha" $=.05$

\section{CONCLUSION}

The results of this examination confirmed past findings detailed. In spite of the above restrictions, the findings of the current investigation are profoundly significant. Its essential outcome in the scale estimating and its fundamental findings concern the connotations with the self-control, happiness, satisfaction with life. Study on self-control has caused it probable to well comprehend human behaviour in different parts of life. Right now, have endeavoured to coordinate what is thought about self-control change, particularly continuing varieties in satisfaction with life. The model incorporates a wide assortment of findings and recommends various new bearings for research. Over many years have gone since the "pursuit of happiness" was part of the number research. We trust it is finally period for the matter of manageable prosperity to be specified the scientific consideration that it merits. Our investigation didn't appear, as we had anticipated, the effect of self-control on the happiness and life satisfaction and both in the gathering of individuals with and with the huge influence of locus of control. The Life satisfaction was anticipated by student's orientation and kind of other healthy activities, gathering, and social interaction may have positively influence on happiness. Which ultimately suggest that if student worker on their self-control it may have better results in different stages of life? Self-Control has been connected to accomplishments in various different backgrounds, and apparently with more prominent poise one could concentrate more on desires and less on warding off obstructions en route. All things considered, despite the fact that the quest for bliss may not be simple, it gives off an impression of being in any case in our control.

The discoveries recommend that there was significantly relationship have among the self-control with happiness and self-control with satisfaction with life. Different independent variables contribute in future research.

\section{REFERENCES}

Bernardi, R. (1997). The Relationships Among Locus of Control, Perceptions of Stress, and Performance, Journal of Applied Business Research. .

Biswas-Diener. (2008). Happiness: Unlocking the Mysteries of Psychological Wealth,oxford.

Cetin, F. (2008). The effects of self concept,locus of control and personality on conflict resolution approaches in interpersonal relation.

Dew (1994). Adolescents' perceived quality of life. An exploratory investigation. Journal of School Psychology, 185-199.

Diener \& Dean. (2008). Happiness: Unlocking the Mysteries of Psychological Wealth Oxford.

Diener. (1985). The Satisfaction with Life Scale. Journal of Personality Assessment, 71-75. 
Diener. (1995). Physical Attractiveness and Subjective Well-being. Journal of Personality and Social Psychology, 69,120-129.

Diener, E. (1995). Resources, personal strivings, and subjective well-being: A nomothetic and idiographic approach. Journal of Personality and Social Psychology.

Diener, E. 1. (2013). Theory and validity of life satisfaction scales. In Social Indicators Research, (pp. 497-527).

Diener, (2011). Needs and subjective well-being around the world. Journal of Personality and Social Psychology, , $354-365$.

Doğan, U., \& Çelik, E. (2014). Examining the factors contributing to students' life satisfaction. Educational Sciences. Theory and Practice, , 2121-2128.

Eldeleklioğlu, J. (2015). Predictive effects of subjective happiness, forgiveness, and rumination on life satisfaction. Social Behavior and Personality, 1563-1574.

Gilman, e. (1997). Children'sreports of their life satisfaction: Convergence across raters, time, and response formats. School Psychology International, 207-241.

Hills, P. (2002). The Oxford Happiness Questionnaire: a compact scale for the measurement of psychological well-being. Personality and Individual Differences, 1073-1082.

Keller ,E. (1983). Motivation design of instruction. In In C.M Re Instructionaldesign theories and models: An overview of their current status (pp. 384-434). USA: Lawrance Erlbaum Associates.

Lewis, A. D. (2010). Facilitating student engagement: The importance of life satisfaction (Doctoral Dissertation). Retrieved from ProQuest Dissertations.

Marks, L. (1998). Deconstructing locus of control: Implications for practitioners. Journal of, 251-260.

Nelson, D. A. (1997). ganizational Behavior: Foundations, Realities, and Challenges.

Pavot, E. D. (1993). Review of the satisfaction with life scale.Cross-cultural correlates of life satisfaction and self-esteem. Psychological Assessment, 164.

Reich, J. W. (2017). Perceived control theory, research, and practice in the first 50 year's. Oxford University Press., 2-20.

Rotter, J. (1966). Generalized expectancies for internal versus external control of reinforcement. Psychol Monogr, 609.

S, e. M. (2006). Is extremely high life satisfaction during adolescence advantageous,. 
Sheldon, K. M. (1995). Coherence and congruence: Two aspects of personality integration. Journal of Personality and Social Psychology.

Shin, D. C., \& Johnson, D. M. (1978). Avowed happiness as an overall assessment of the quality of life. Social Indicators Research, 475-492.

Suldo, e., al S.M., e., \& al K.N Riley, S. (2006). Academic correlates of children and adolescents 'life satisfaction. School Psychology International.

Zhang, e., al L., L. e., \& J., a. (2002). Moderating effects of gender and age on the relationship between self-esteem and life satisfaction in mainland Chinese. International Journal of Psychology, 37-83-91.

\section{APPNENDICES}

Supplemental Materials

Appendix A. Items and Response Scales for Study Measures

(A)

\begin{tabular}{|l|}
\hline Self-control \\
\hline 1. I am good at resisting temptation. \\
\hline 2. I have a hard time breaking bad habits. \\
\hline 3. I am lazy. \\
\hline 4. I say inappropriate things. \\
\hline 5. I do certain things that are bad for me, if they are fun. \\
\hline 6. I refuse things that are bad for me. \\
\hline 7. I wish I had more self-discipline. \\
\hline 8. People would say that I have iron self-discipline. \\
\hline 9. Pleasure and fun sometimes keep me from getting work done. \\
\hline 10. I have trouble concentrating. \\
\hline 11. I am able to work effectively towards long-term goals. \\
\hline 12. Sometimes I can't stop myself doing something, even if I know it is wrong. \\
\hline 13. I often act without thinking through all the alternatives. \\
\hline
\end{tabular}

\section{(B)}

\section{Happiness}

I don't feel particularly pleased with the way I am.

I am intensely interested in other people.

I feel that life is very rewarding.

I have very warm feelings towards almost everyone.

I rarely wake up feeling rested.

I am not particularly optimistic about the future.

I find most things amusing. 


\begin{tabular}{|l|}
\hline I am always committed and involved. \\
\hline Life is good. \\
\hline I do not think that the world is a good place. \\
\hline I laugh a lot. \\
\hline I am well satisfied about everything in my life. \\
\hline I don't think I look Attractive. \\
\hline There is a gap between what I like would to do and what I have done. \\
\hline I am very happy. \\
\hline I find beauty in Some things. \\
\hline I always have a cheerful effect on others. \\
\hline I can fit in (find time for) everything I want to. \\
\hline I feel that I am not especially in control of my life. \\
\hline I feel able to take anything on. \\
\hline I feel fully mentally alert. \\
\hline I often experience Joy and elation. \\
\hline I don't find it easy to make decisions. \\
\hline I don't have a particular sense of meaning and purpose in my life. \\
\hline I feel I have a great deal of energy. \\
\hline I usually have a good influence on event. \\
\hline I don't have fun with other people. \\
\hline I don't feel particularly healthy. \\
\hline I don't have particularly happy memories of the past. \\
\hline
\end{tabular}

\section{(C)}

\section{Satisfaction with life}

In most ways my life is close to my ideal.

The conditions of my life are excellent.

I am satisfied with my life.

So far I have gotten the important things I want in life.

If I could live my life over, I would change almost nothing.

\section{(D)}

\section{Locus of control}

I usually get what I want in life.

I need to be kept informed about news events.

I never know where I stand with other people.

I do not really believe in luck or chance.

I think that I could easily win a lottery.

If I do not succeed on a task, I tend to give up.

I usually convince others to do things my way.

People make a difference in controlling crime.

The success I have is largely a matter of chance.

Marriage is largely a gamble for most people.

People must be the master of their own fate.

It is not important for me to vote. 
. My life seems like a series of random events.

I never try anything that I am not sure of.

I earn the respect and honors I receive.

A person can get rich by taking risks.

Leaders are successful when they work hard.

Persistence and hard work usually lead to success.

It is difficult to know who my real friends are.

Other people usually control my life.

\section{Copyrights}

Copyright for this article is retained by the author(s), with first publication rights granted to the journal. This is an open-access article distributed under the terms and conditions of the Creative Commons Attribution license (http://creativecommons.org/licenses/by/4.0/) 